\title{
KALTBACH CAVE (SIEBENHENGSTE, SWITZERLAND): PHANTOM OF THE SANDSTONE?
}

\author{
JAMA KALTBACH (SIEBENHENGSTE, ŠVICA): \\ FANTOM V PEŠČENJAKU?
}

PHILIPP HÄUSELMANN ${ }^{1} \&$ PAOLA TOGNINI ${ }^{2}$

${ }^{1}$ Institut für Angewandte Geologie, Universität für Bodenkultur, Peter Jordan Str. 70, 1190 Vienna, Austria, praezis@geo.unibe.ch

2 via Santuario Inferiore 33/D, 23890 Barzago (LC), Italia, paolatognini@iol.it 


\section{Abstract}

UDC: 911.2:5551.44(494)

Philipp Häuselmann \& Paola Tognini: Kaltbach cave (Siebenhengste, Switzerland): Phantom of the Sandstone?

Kaltbach cave is developed within the Eocene Hohgant sandstone in the Siebenhengste area in Switzerland. A remapping project of the cave resulted in a huge increase in length. It also produced a complete, updated map and longitudinal section. The cave's morphology does not fit with the "normal" speleogenesis: it is a so-called phantom cave. Phantoms are created by differential weathering of impure limestone under a preferably warm climate and a very low hydrologic gradient. Once the gradient steepens, the undissolved residual sediments are piped out; the "cave" manifests itself. The paper discusses the geomorphological features that permit to recognize the phantom caves.

Key words: impure carbonate, speleogenesis, Siebenhengste, weathering, piping, cave morphology.

\section{Izvleček}

UDK: 911.2:5551.44(494)

\section{Philipp Häuselmann \& Paola Tognini: Jama Kaltbach (Siebenhengste, Švica): Fantom v peščenjaku?}

Jama Kaltbach je razvita v Hochgantskem eocenskem peščenjaku na območju Siebenghengste v Švici. Rezultat ponovne izmere jame je precej večja dolžina, nov načrt jame in številna opažanja, ki kažejo na to, da jama ni nastala $\mathrm{z}$ »normalno speleogenezo«, ampak je t.i. fantomska jama. Fantomske jame nastajajo pri delnem preperevanju nečistega apnenca v toplih klimah, v pogojih nizkega hidravličnega gradienta. Ob povečanju gradienta, voda izpere netopni preostanek, pri čemer nastane jama. Članek obravnava geomorfološke značilnosti jam, ki nam omogočajo prepoznavati fantomske jame.

Ključne besede: nečisti karbonati, speleogeneza, Siebenhengste, cevljenje, preperevanje, jamska morfologija. 


\section{INTRODUCTION}

Kaltbach cave develops in more calcareous layers of the Eocene Hohgant sandstone which forms the caprock above the main karst aquifer in the Siebenhengste area (Fig. 1). This sandstone caprock contains several caves and parts of caves. For instance, the entrance parts of Bärenschacht and Faustloch are developed within the Hohgant series. Kaltbach cave was discovered as a strongly

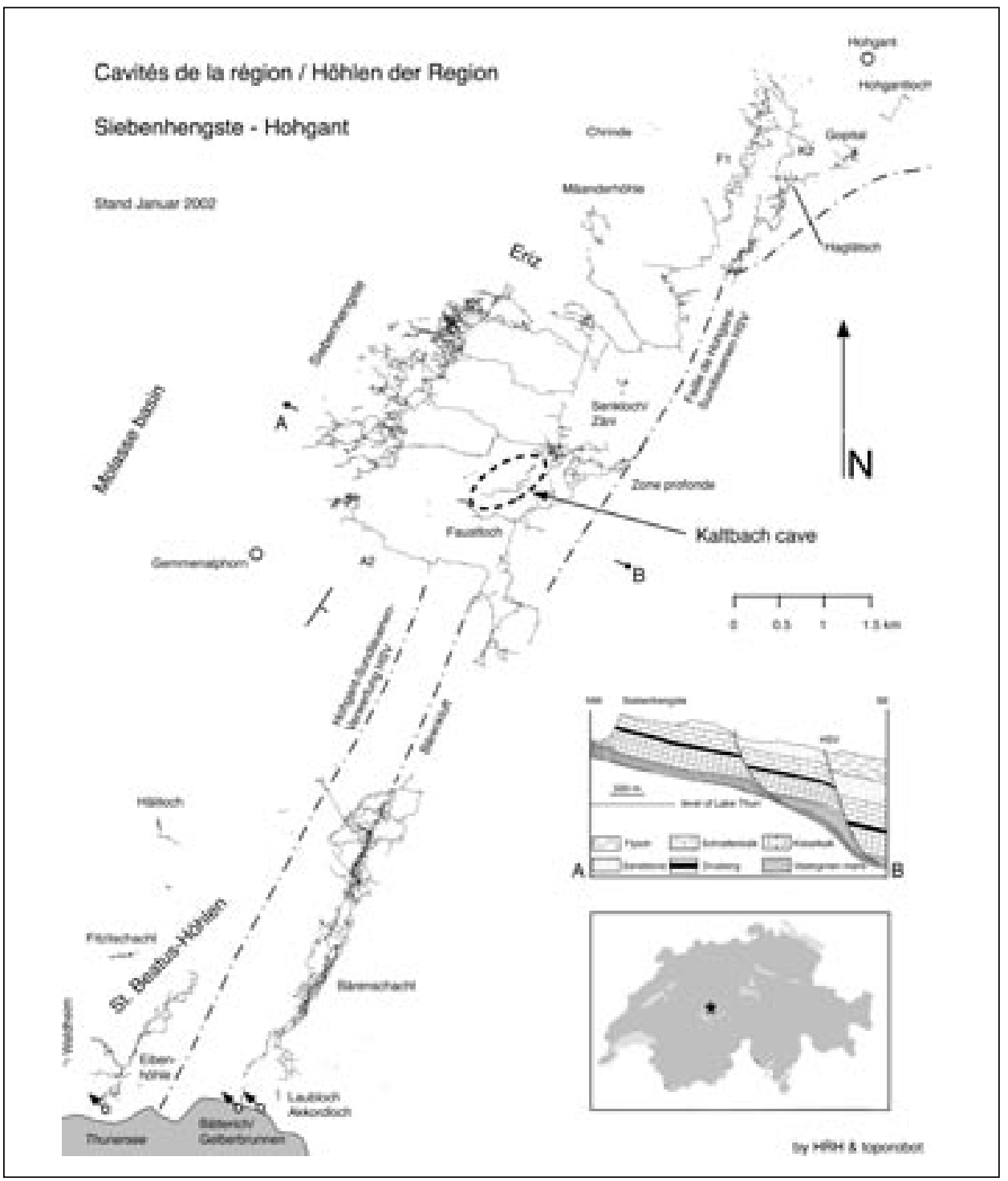

Fig. 1: Overview of the Siebenhengste region with the caves. A geologic cross-section shows the sandstone overlying the limestone. 
ventilating hole in 1977. Once the entrance enlargened, the cave was surveyed to a length of $70 \mathrm{~m}$. After that, some expeditions went into the cave, but there was basically no written description. Only several years later, a map sketch was found that didn't fit with the published plan. So, remapping began in 1992 in order to discover the missing link. Due to passages blocked by water or gravel, the mapping lasted until 2002, but there were a lot of new passages found, making it the longest cave in the Siebenhengste sandstone so far, with a total length of $1672 \mathrm{~m}$.

During the remapping project, it was found that the cave has a somehow intriguing morphology that made it very difficult to get information about the cave's genesis. Might it be that the cave is actually a so-called "phantom"?
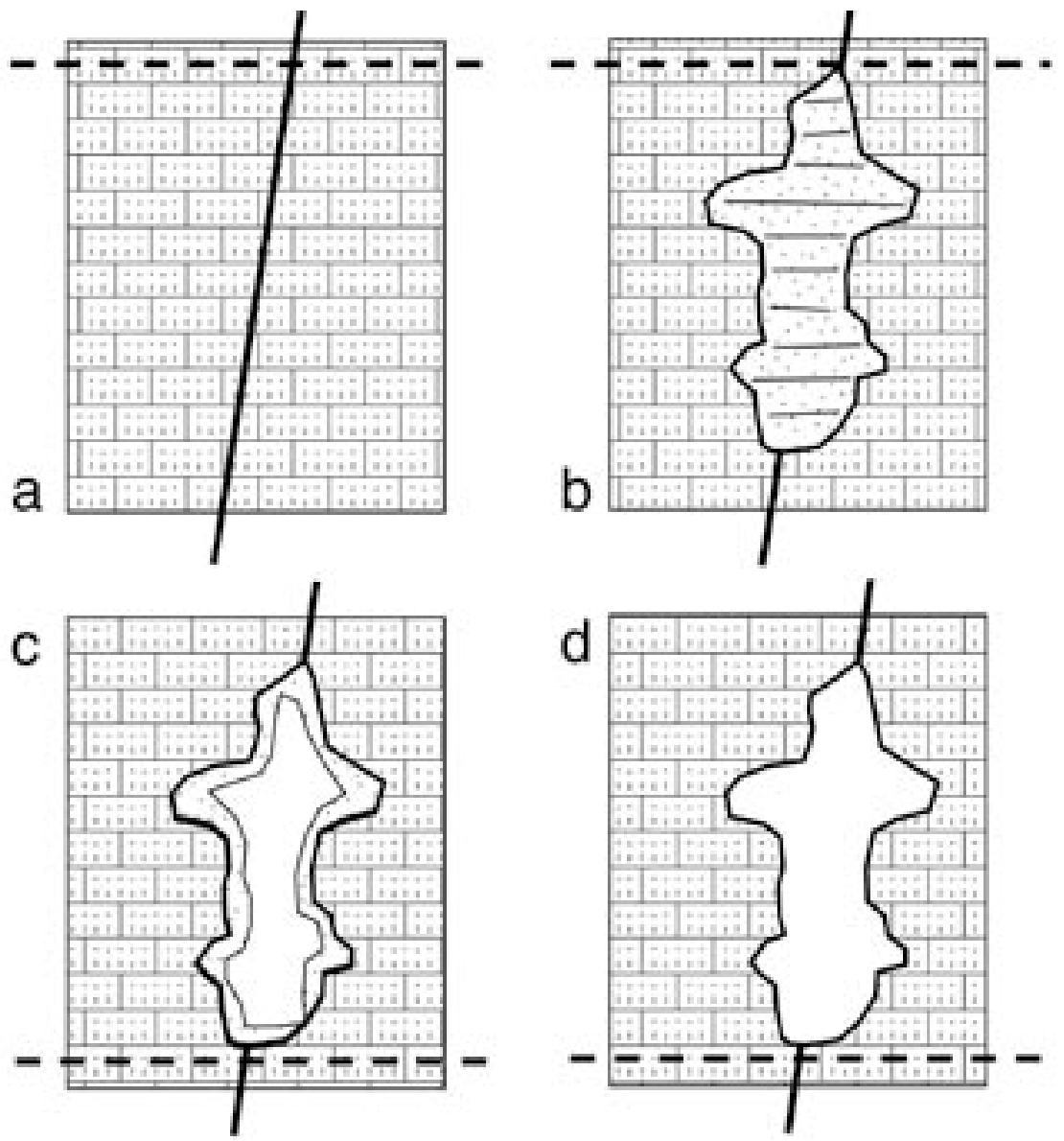

Fig. 2: Genesis of phantom caves, simplified. For explanation see text. Dashed line: water table. 


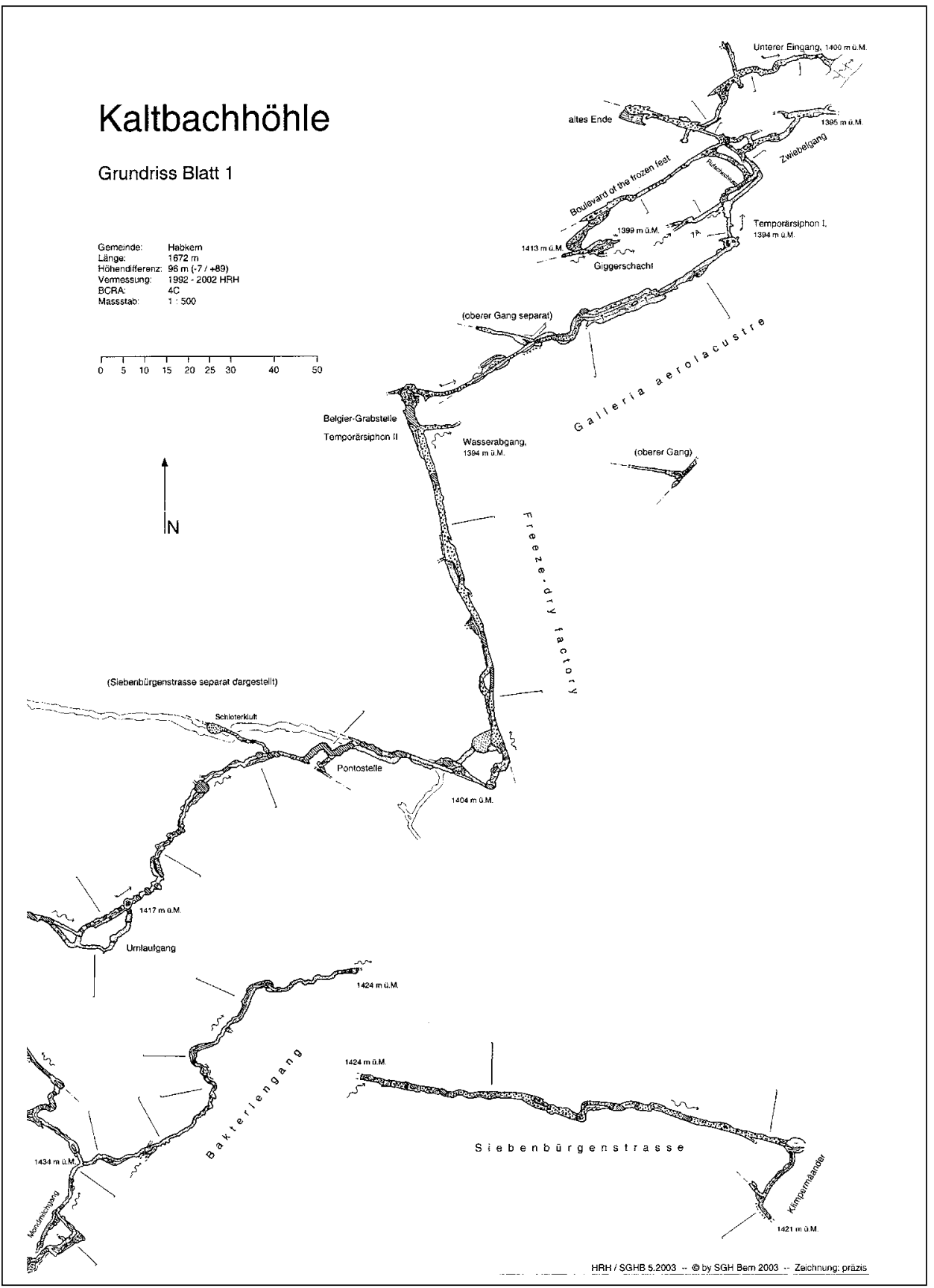

Fig. 3a: Complete map of Kaltbach cave. The dependance of fracturization is quite easily visible on the map. It is not the most striking example, though. 


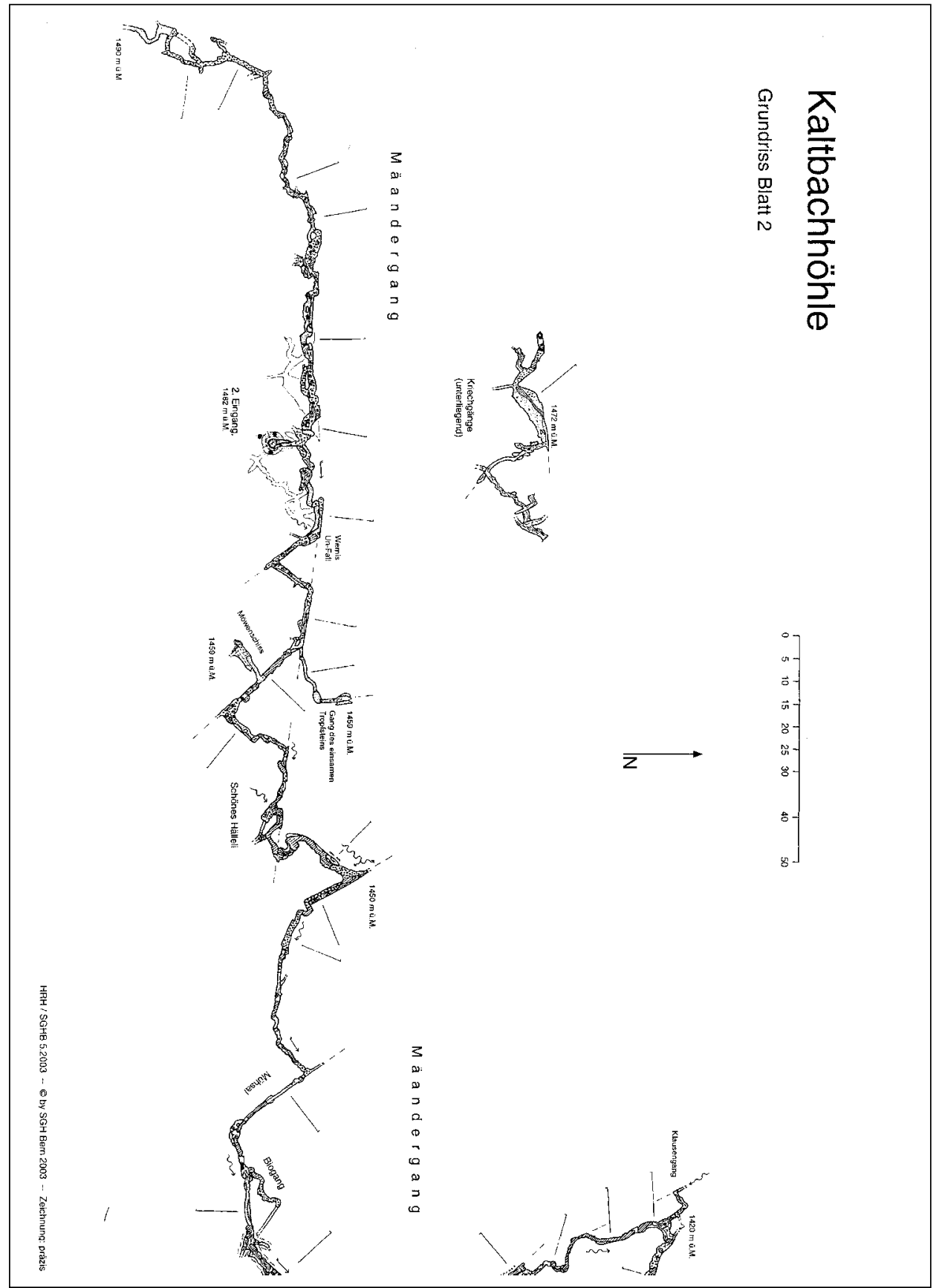

Fig. 3b: Complete map of Kaltbach cave. The dependance of fracturization is quite easily visible on the map. It is not the most striking example, though. 
Philipp Häuselmann \& Paola Tognini: Kaltbach Cave (Siebenhengste, Switzerland): Phantom of the Sandstone?

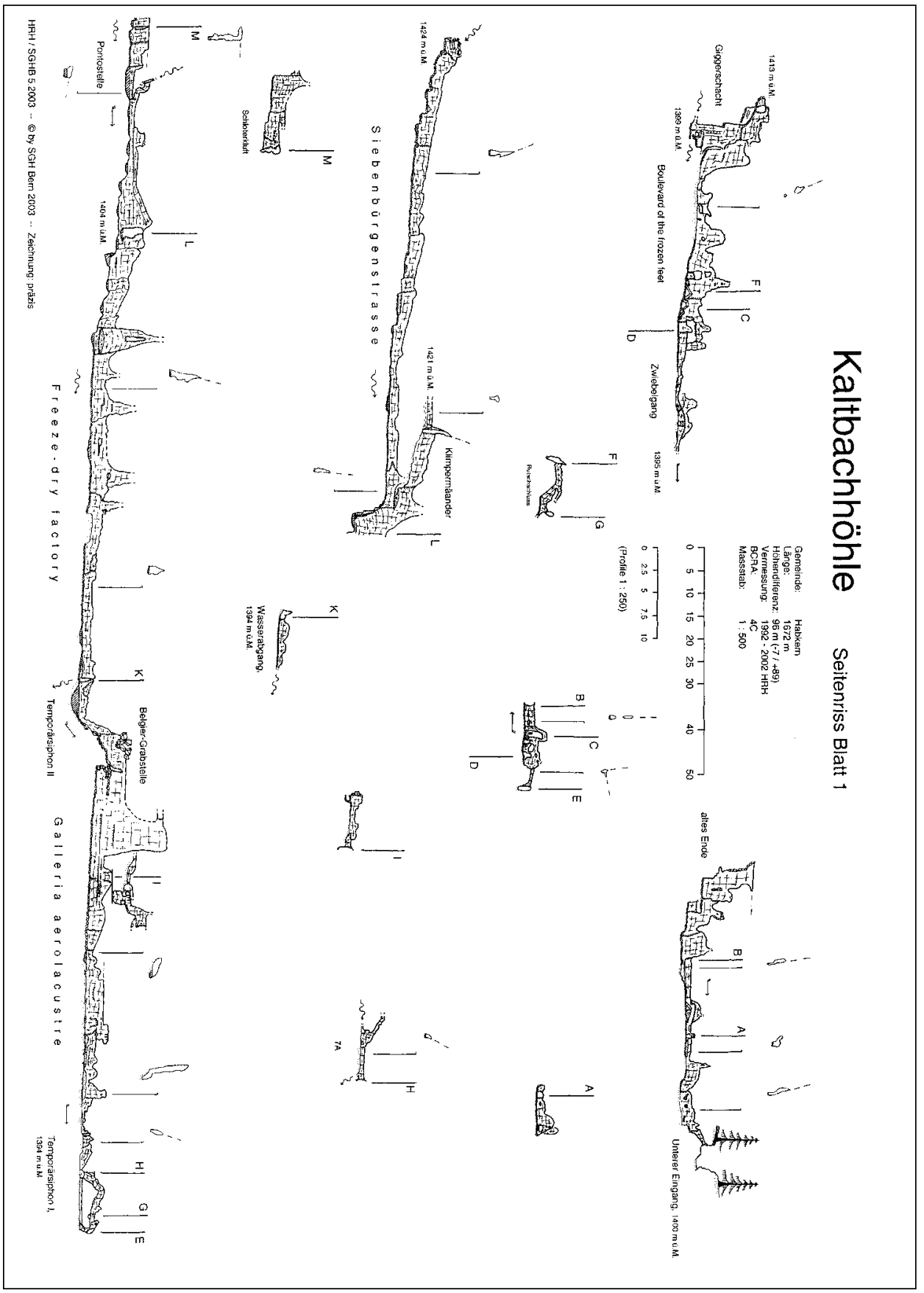

Fig. 3c: Longitudinal section of Kaltbach cave. 


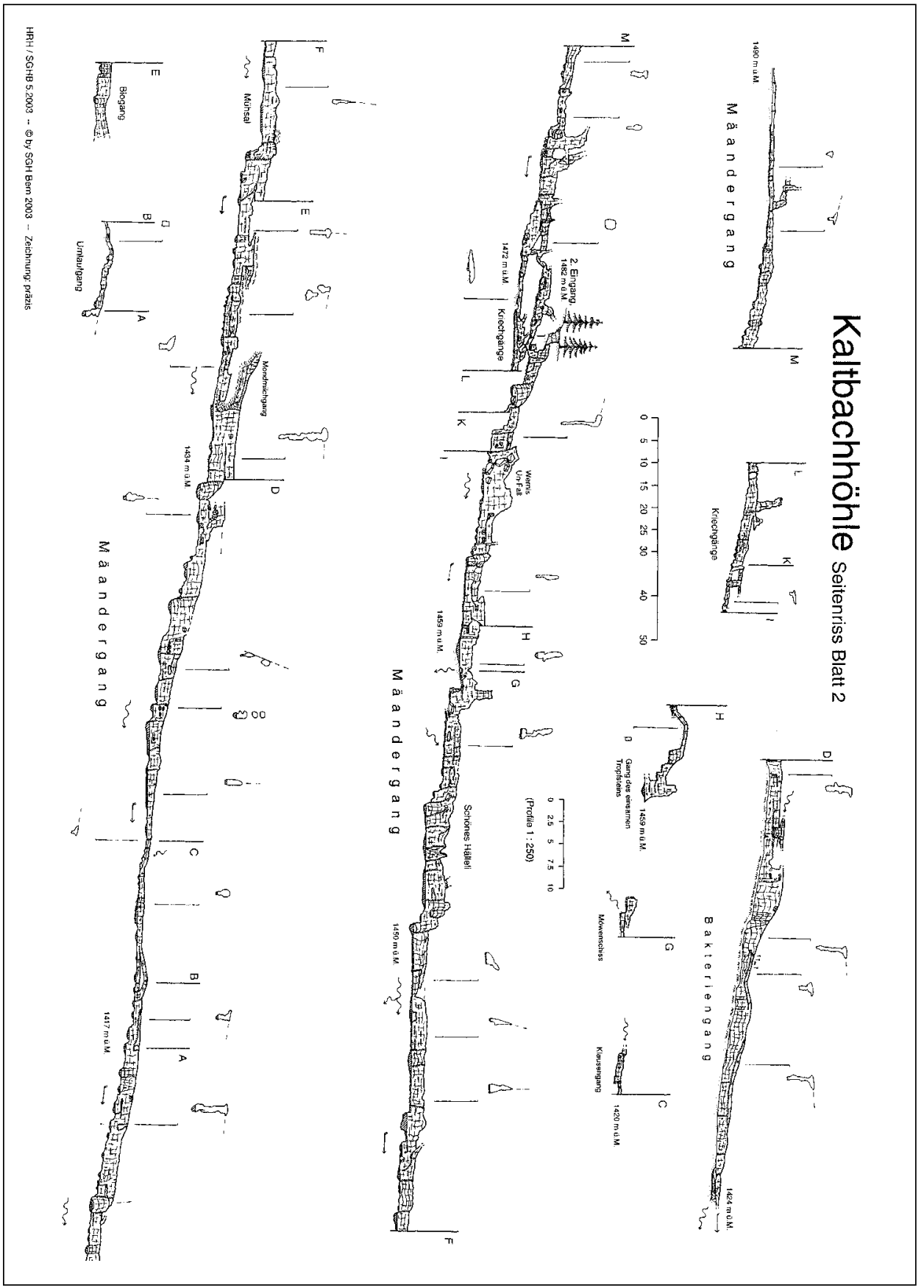

Fig. 3d: Longitudinal section of Kaltbach cave. 


\section{WHAT ARE PHANTOMS?}

The description of phantoms and the forces creating them was already published by belgian researchers (Vergari \& Quinif 1997, Vergari 1998, Quinif 1999) However, most of these publications are in french language; thus the subject is still not very known to english-speaking cavers. Therefore, we'll briefly present how the phantoms form and how they look like.

Most usually, the development of phantoms is related to impure carbonate rocks which are composed of insoluble particles with a carbonate cement (Tognini 1999). Investigations have shown that basically the same process is responsible for the genesis of the Quartzite caves (Martini 2000, Correa Neto 2000). Some scientists even suggested that phantoms may develop in packstones with a dissolutional contrast between the biogenic particles and the cement. This latter possibility, however, is probably of minor importance.

The next requirement is fracturization of the host rock that permits water to enter (Fig. 2a). The last, but most important, requirement is that there is almost no watertable gradient and a climate that favours corrosion (i.e. vegetational cover) and/or pedogenetic weathering. Under these circumstances, the water seeping into the limestone has the possibility to dissolve the carbonate, but because of the low gradient, it has not enough power to transport the residual particles which are left in place (Fig. 2b). The porosity, however, increases and permits more water to reach the rock whose cement is gradually dissolved.

Once the gradient gets steeper (uplift, valley deepening), the more or less cohesion-less particles are piped out by the increased transport energy of the water: a cave develops. Sometimes not all the weathered material is piped out (Fig. 2c), sometimes, however, the hole is emptied (Fig. 2d).

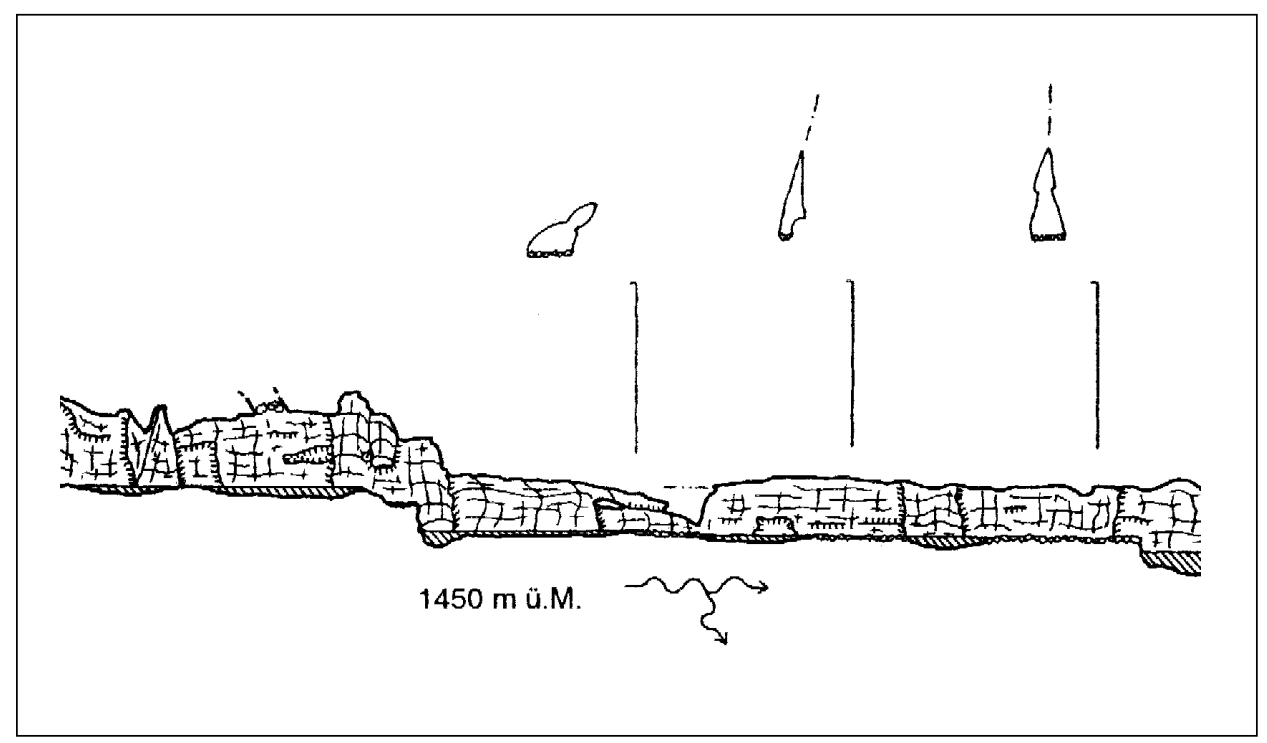

Fig. 4: A meander (left side) gradually transforms into a phreatic shape (middle), before turning back into vadose morphology (right). 


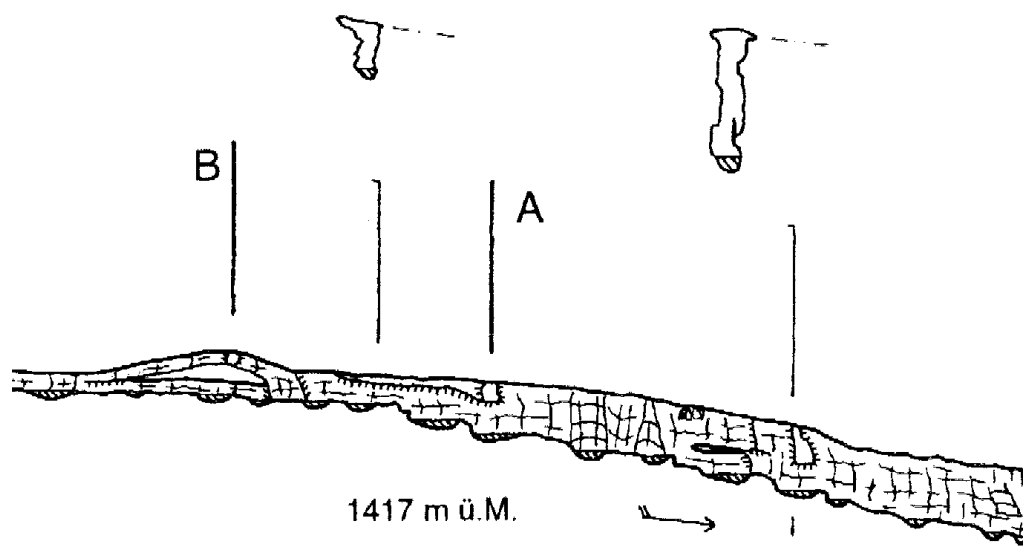

Fig. 5: The changes in passage size are not very well visible, since the cross-section on the left side is missing. However, the passage there has a (phreatic-like) cross-section of less than $1 \mathrm{~m}^{2}$, while the passage that continues on the right side has a size of about $3.5 \mathrm{~m}^{2}$.
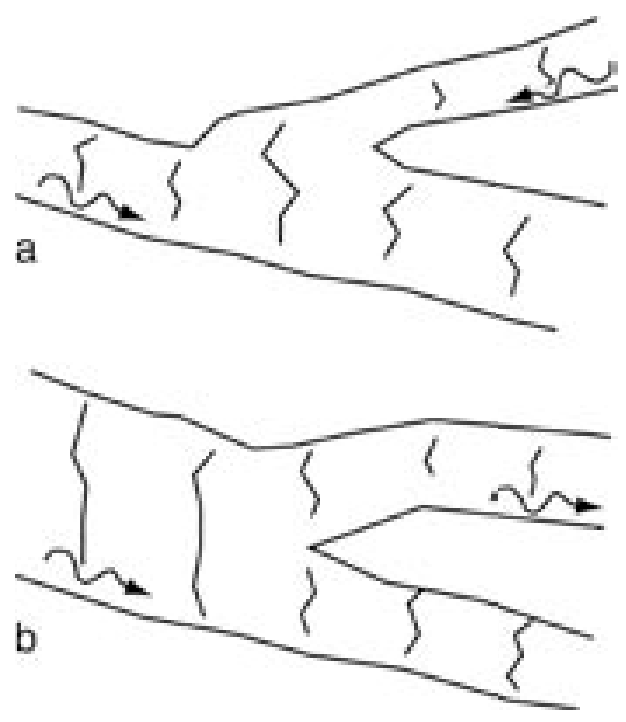

Fig. 6: Illustration for the meander "going up". Fig. 6a illustrates the "normal vadose" genesis of a meander passage where two rivers meet. Fig. $6 b$ shows a meander to the left. If created under normal vadose conditions, the upper meander also would be vadose, hence top AND bottom of that meander should be at least horizontal or dipping to the right. This scenario is often observed. However, if we assume a phantomic genesis, the "meander" could also point upwards, as shown in the figure. 
How does a phantom cave differ from a "normal" cave? In the following part, the text will be accompanied by excerpts from the Kaltbach map which is represented in its entirety as figure 3 .

\section{MORPHOLOGICAL PECULIARITIES}

Phantomisation may not only be seen underground, but also at the surface. The most often encountered features are remnant pillars and gorges, many of which present striking differences in shape and size.

The most important of the underground features of phantoms is that phreatic tube-like morphologies can change into vadose-like "meander" shapes and back again without having to obey to the speleogenetic laws (Fig. 4). More than that, there may be big changes in diameter of a passage (Fig. 5). Changes like that, in "normal" caves, can only be explained by sediment infill or the hidden presence of a lateral passage.

Another very interesting feature, however quite seldom observed, is what one might call "upward meanders". It is well known that a meander might split itself into two branches (which usually connect after some time again). However, since a meander is a vadose form, the water always had to flow in the downstream direction (Fig. 6a). In a phantom cave, a meander can split, but the upper end of the meander goes up instead of down (Fig. 6b, 7). This is only possible in phantom conditions.

Natural bridges and pillars are often more frequent in phantoms than in normal vadose caves (it is well-known that they may be very common in the phreatic realm). So, if the morphology is rather related to a vadose cave, but there are a lot of natural bridges, it could be a phantom.

The last morphological feature, however not very distinct, is that passages often seem to stop in a dead end. Alas, this morphology may also be caused by other processes than phantomization.

One of the most characteristic and striking features of phantoms is the ending of a passage in "sediment fill". This "fill" actually conserved the bedding planes of the host rock, although it is completely cohesionless, and represents the insoluble residues that were not piped out (Fig. 2b). Sadly enough, this very convincing feature is not found very often, for instance, Kaltbach cave has no indication of that.

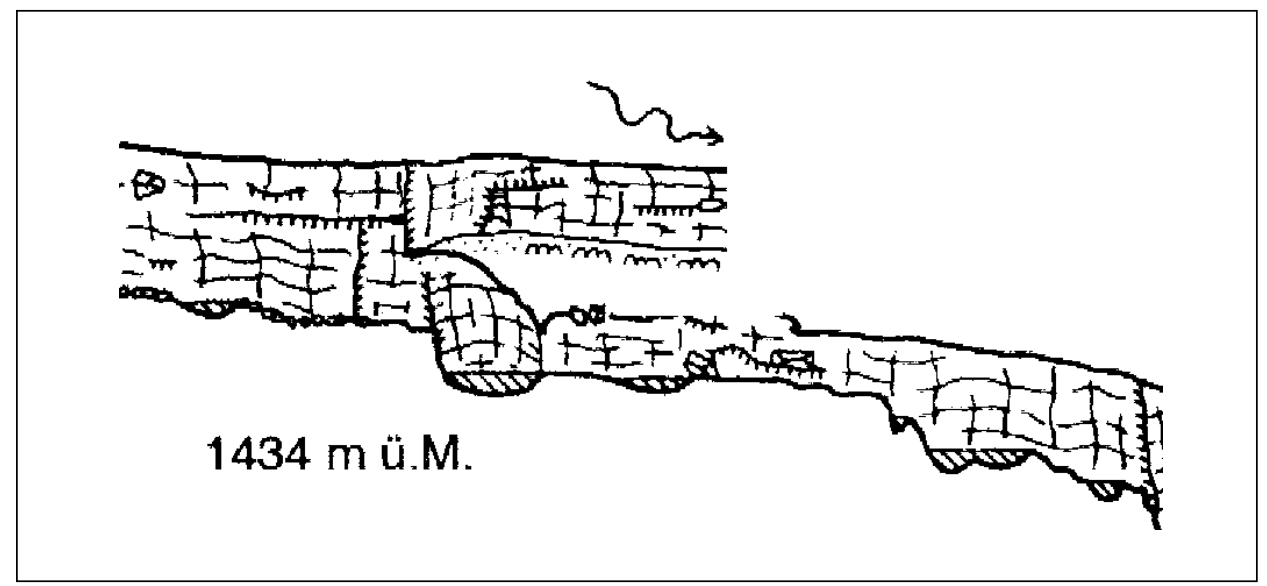

Fig. 7: The beginning of Bakteriengang (top middle) is an example of a meander "going up". 
There are two additional features that may reveal the presence of a phantom. On one hand, it is the plan pattern of the cave, which is strongly dependent on fracturization (Fig. 3). This is, however, not typical for phantoms since many "normal" caves also show the same dependence. The main difference is that in phantoms, almost all joint sets are used, since there is no gradient controlling a preferential direction. Of course, the later piping is controlled by gradient, so, it might be that not all used joints are emptied.

Dirty, weathered walls may be remnants of a phantomisation (and Kaltbach cave has a lot of that, Fig. 8), but it might very well be that the cave walls weathered by action of meteoric water long after the cave was created by "normal" speleogenetic processes (Zupan Hajna 2003).

Passages with straight and smooth walls, which could be of breakdown origin, often do not show neither boulders on the floor nor signs of the water that could have dissolved the blocks away. This feature is not seen in Kaltbach cave, most of the cave being occupied by a small river.

As it is usual, the abovementioned features cannot stand alone to be proof of a phantom, but if they appear together in a cave, there is a high chance that it might really be a phantom cave.

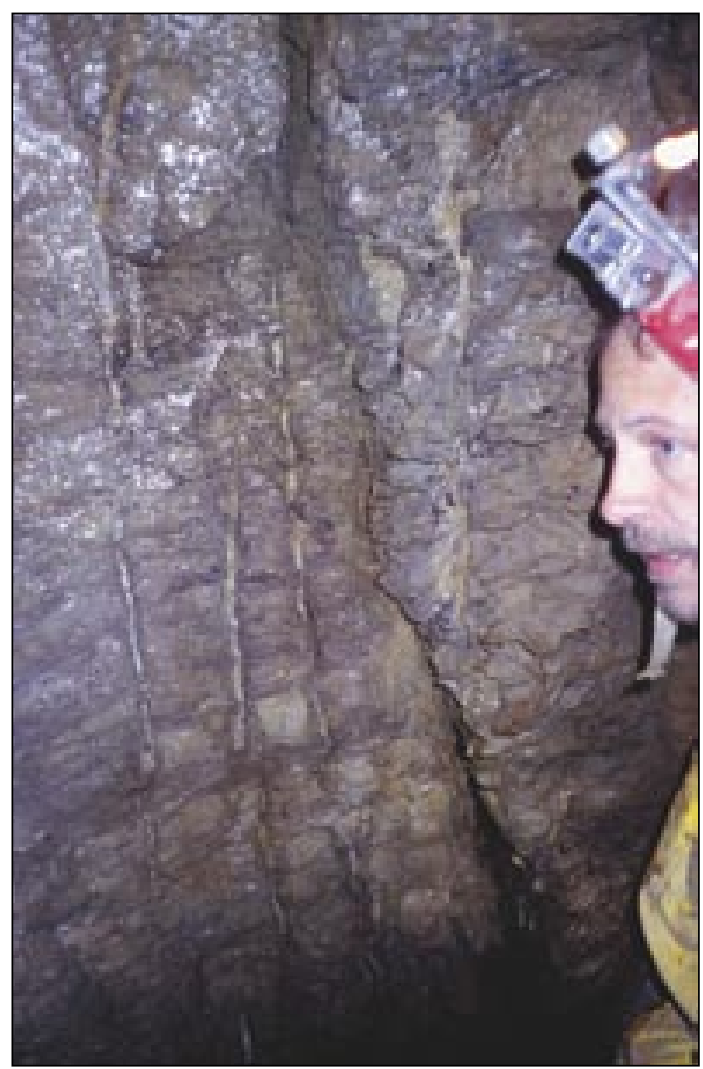

Fig. 8: Picture of dirty walls, caused either by sediment remnants of the phantomization or by more recent weathering of the walls. Photo Mauro Inglese. 


\section{CONCLUSION}

The number of features that hint to a phantomic genesis of Kaltbach cave are numerous. In addition to that, some of the presented features cannot be explained by "normal" speleogenesis. However, some indications are not as clear. We can thus deduce that Kaltbach cave is at least partially a phantom. It actually is probably not the only phantom on the Siebenhengste area. The well-known Tropfloch (von Arx, Martignoni \& Koenig 1970) on Siebenhengste probably is also one.

We thus can deduce that phantoms may occur among the best cave families. However, with proper treatment (drawing of longitudinal sections!), we can discover them quite easily.

\section{ACKNOWLEDGEMENTS}

The idea to write this paper came upon realizing that the phantomization of impure limestones is still hardly known to the english-speaking cavers. I am greatly indebted to Anne Vergari and Yves Quinif who initially discovered the phantoms. Paola Tognini agreed to accompany me and to confirm my theories about Kaltbach cave, and Mauro Inglese is thanked for photos. The present article is part of a project on speleogenesis in the Alps of the BOKU Vienna.

\section{REFERENCES}

Correa Neto, A.V., 2000: Speleogenesis in quartzite in southeastern Minas Gerais, Brazil. In: A. Klimchouk, D. C. Ford, A. N. Palmer, \& W. Dreybrodt (Eds.), Speleogenesis: Evolution of karst aquifers (pp. 452-457). Huntsville: NSS.

Martini, J.E.J., 2000: Dissolution of quartz and silicate minerals. In: A. Klimchouk, D. C. Ford, A. N. Palmer, \& W. Dreybrodt (Eds.), Speleogenesis: Evolution of Karst Aquifers (pp. 171174). Huntsville: NSS.

Quinif, Y., 1999: Fantômisation, cryptoaltération et altération sur roche nue, le triptyque de la karstification. - Etudes de géographie physique, suppl. XXVIII, 159-164.

Tognini, P., 1999: The Mt. Bisbino (Northern Italy) karst: a new speleogenetic process. - Etudes de géographie physique, suppl. XXVIII, 185-190.

Vergari, A., 1998: Nouveau regard sur la spéléogenèse: le "pseudo-endokarst du Tournaisis (Hainaut, Belgique). - Karstologia, 31(1), 12-18.

Vergari, A. \& Y. Quinif, 1997: Les paléokarsts du Hainaut. - Geodinamica Acta, 10(4), 175-187.

von Arx, M., P. Martignoni \& L. Koenig, 1970: Die Seefeldhöhle. - Forschungsbericht, Berner Höhlenforscher, $80 \mathrm{p}$.

Zupan Hajna, N., 2003: Incomplete solution: Weathering of cave walls and the production, transport and deposition of carbonate fines. - Postojna: Založba ZRC, 167 p. 
